\title{
Darya Ogorodnikova Exploring Paratexts in Old Mande Manuscripts
}

\section{Introduction}

Manuscripts produced by scholars from the Mande-speaking area constitute an important part of West Africa's Islamic manuscript traditions. ${ }^{1}$ These manuscripts are written in either Arabic or vernacular languages that are rendered in Arabicbased scripts known as Ajami. Recent decades have witnessed the emergence of several works on a variety of manuscripts written in different Mande languages with texts ranging from chronicles, poetry and personal correspondence to medical and talismanic manuals. ${ }^{2}$ This scholarship focuses overwhelmingly on texts, however, and examines them mainly from the perspective of linguistics, history and anthropology; few attempts have been made to concentrate on the manuscripts themselves or to analyse their codicological and palaeographical characteristics in any great detail.

Another group of manuscripts presenting attestations of Mande languages remained unnoticed until 2012 when Nikolay Dobronravin discovered a major

I would like to express my gratitude to Dmitry Bondarev for his valuable comments on the previous drafts of this paper and to Tal Tamari for her constant advice at various stages of this study and her most valuable information on the history, anthropology and Islamic education of the Manding people. My thanks also go to Valentin Vydrin for his important suggestions and remarks on linguistic aspects of the Mande languages. The research for this article was carried out within the scope of the work conducted by the SFB 950 'Manuskriptkulturen in Asien, Afrika und Europa' / Centre for the Study of Manuscript Cultures (CSMC), Hamburg, funded by the German Research Foundation (Deutsche Forschungsgemeinschaft, DFG).

1 The Mande language family comprises up to 60 languages, including Bamana, Maninka, Mandinka, Juula and Soninke, which are spoken in modern-day Senegal, the Gambia, Guinea-Bissau, Mali, Mauritania, Guinea, Ivory Coast and Burkina Faso. The first three states, which are often mentioned together throughout this article, are sometimes collectively referred to as Southern Senegambia. However, this term is rather problematic as the borders of the area it denotes do not exactly match those of Senegal, the Gambia and Guinea-Bissau. I therefore prefer to mention each country independently.

2 Schaffer 1975; Hamès 1987; Tamari 1994; Vydrine 1998; Giesing / Vydrine 2007; Ngom 2010; Donaldson 2013; Vydrin 2014; Vydrin / Dumestre 2014. 
collection of them in the Library of Trinity College, Dublin. He also pointed to cataloguing entries in other European libraries which were suggestive of similar Mande material. His intuition eventually turned out to be right. The main texts in these manuscripts are written in Arabic, and annotations have been made in the vernacular. The works are referred to as 'Old Mande manuscripts' - the label Old Mande was first suggested by Dobronravin and is henceforth abbreviated to 'OM' in this article - since the language used in the annotations is closely related to Soninke, but it is likely to represent its earlier stage. ${ }^{3}$ Since 2012, many more OM manuscripts have been identified in other European libraries.

The corpus of OM manuscripts hitherto identified comprises more than seventy different codicological units whose size varies from one folio to several hundred of them. ${ }^{4}$ Most of the manuscripts are in the form of loose leaves and are kept unbound along with their original covers, but some were later bound by European librarians. ${ }^{5}$ These manuscripts cover a wide range of subject matter, includ-

3 Soninke is a language spoken primarily in Mali and Mauritania, but also in Senegal, the Gambia, Guinea-Bissau and Burkina Faso. According to some native speakers of Soninke, the language of glosses in manuscripts is difficult to understand because it contains not only many loanwords from Arabic, but also some specialised vocabulary for interpreting religious texts. The extent to which the language of the glosses differs from modern-day spoken Soninke is still unclear. On the one hand, the linguistic variation may be due to the passage of time, while on the other, it is also possible that the language of the glosses was a specialised scholarly register used by Muslim Soninke speakers in the context of Islamic education, with the vocabulary and grammar having been developed for better interpretation of the Arabic texts. On the use of the vernacular languages in exegetical practices, see Bondarev 2013, 2014; Bondarev / Tijani 2014; Davydov 2012; Dobronravin 2013; Tamari 1996, 2002, 2005, 2006, 2009, 2013a, 2013b; Tamari / Bondarev 2013. Moreover, it is possible that an OM language once existed, which was closely related to Soninke. It might have had a special status as an exegetical language and as such was used among the Muslim communities who spoke different Mande languages across a vast area under the spiritual influence of the Soninke scholars. 4 The largest group of these OM manuscripts (more than 30) is kept by the Bibliothèque nationale de France (BnF) in Paris. Others are to be found in the University Library, Leiden (ULL) (ca. 6), the John Rylands Library (JRL) in Manchester (ca. 12), the Palace Green Library (PGL) of the University of Durham (ca. 3), Trinity College in Dublin (TCD) (ca. 8), the Bibliothèque Universitaire des Langues et Civilisations (BULAC) in Paris (ca. 13) and the Bibliothèque de l'Institut Fondamental d'Afrique Noire (IFAN) in Dakar (1 unit). In addition, the Institut de Recherche et d'Histoire des Textes (IRHT) in Paris has several microfilms of manuscripts kept in the collections of the ex Musée national des Arts d'Afrique et d'Océanie (MAAO) and the Bibliothèque Municipale de Tours (BMT). 5 Many OM manuscripts found in European libraries consist of several codicological units written by different hands on different kinds of paper. In some cases, it is hard to say whether these units were put together by West African scholars or later by European librarians. In many cases, the foliation was added after the manuscripts were acquired by the library, although the order of the pages 
ing theological treatises, Islamic law, religious poetry, and medicinal and talismanic texts. So far, little has been discovered about the origin and date of the $\mathrm{OM}$ manuscripts. Very little information is provided in the catalogue entries and acquisition notes, from which we learn that some of them may have come from Senegal, the Gambia and Mali and they were most probably produced sometime between the eighteenth and twentieth centuries.

To the best of my knowledge, no comprehensive study has yet been done to examine the paratexts in OM manuscripts; this article is the first attempt to analyse their various paratextual components, in particular those containing information about their production, date and origin. Particular attention is given to three types of paratexts: (a) colophons, (b) glosses and (c) prefatory materials.

Colophons written at the end of manuscripts are at the heart of my enquiry. Most commonly, it is here that one can find relevant information about the production, ownership and transmission of manuscripts, including the names of their scribes and owners, the names of the place where they were produced, and the time and purpose of writing or copying them. This study is based on thirty manuscripts which contain colophons out of a total of seventy available OM manuscripts; the other forty manuscripts either do not have any notes left by the scribe (or copyist) or their last page - where one might expect to find a colophon - is missing. ${ }^{6}$ Prefatory matters are also investigated in this article, because the names of authors and/or titles of texts quite often appear after the words basmalah, or bism Allāh ('in the name of God'), thereby opening a composition. Furthermore, various glosses, which usually appear interlineally or in the margins of the main text in Arabic, also provide important insights into the production and transmission of a manuscript. Frequently, the layout was specially designed, with ample space to accommodate glosses added by a later hand.

After providing a general description of the characteristics of various paratextual elements in the OM manuscripts, I shall focus on describing several case studies that are representative of the Mande manuscript tradition. Drawing on the approaches developed by Dmitry Bondarev for Old Kanembu manuscripts, ${ }^{7}$ it will be shown that the glosses that were used to explain the texts and their grammatical structure can give clues to trace the geographical origin of the manuscripts. An indication of time is

is not always correct. In this study, the number of folios in each codicological unit has been indicated. Sometimes there is no foliation available, as in the case of several composite manuscripts from BULAC, which I examined in October 2013. I made digital images (DI) of these manuscripts and assigned them reference numbers, which are those used in this article.

6 For example, none of the fragmentary manuscripts in the collection of ULL has a final page.

7 Bondarev 2013 and 2014. 
only provided occasionally in the manuscripts studied here - most of them provide incomplete information, which is often limited to naming the day of their completion. By investigating colophons, prefatory matters and glosses, a more nuanced but by no means full - understanding of the production and transmission of the OM manuscripts can be attained.

\section{Personal names and place names}

\subsection{Authors and titles of texts}

Names of authors and titles of the texts usually appear in prefatory materials. In the case of authors whose dates of birth and death are known, the mention of their names already provides a first terminus post quem for the manuscript containing their texts. With such information available, it is then possible for modern scholars to locate a manuscript within a time span of approximately a hundred years. ${ }^{8}$

\subsection{Owners}

In many of the OM manuscripts examined here, the personal names of the owners of individual manuscripts are found in colophons, introduced by the Arabic phrase șāhibu hadha-l-kitāb ('owner of this book') or șāhibuhu ('its owner'). Such indications of a manuscript's ownership usually include both the given and the family (clan) name of the person together with genealogical information, sometimes also along with honorific titles and/or nicknames. The name of a manuscript's owner can also be found in other places within the manuscript. In such instances, the name is often written in a decorated frame in the margin of a folio together with the title of the text or a division marker that indicates a portion of the text such as half of it, a third or a quarter. If a name appears in these places, there is usually no further genealogical information accompanying it, not even a family name.

8 One of such examples where we can identify the terminus post quem, BnF Ms Arabe 5657, fols. $1 \mathrm{a}-28 \mathrm{~b}$, will be presented in more detail in the following section. There is another example in which part of manuscript JRL 780 [825], fols. 1a-12b, was erroneously dated in the catalogue as being produced in the mid-seventeenth century. However, information about the date of the author's death reveals that the text could not have been written before the end of the eighteenth or the beginning of the nineteenth century. 


\subsection{Scribes and copyists}

While the names found in the colophons most frequently refer to the owners of the manuscript, names of scribes or copyists sometimes also appear in colophons, often following Arabic words such as kātib ('scribe') or 'alá yad ('in the hands of', 'by'). In some cases, it is specified whether the owner of the book also had the laborious task of copying it or whether the scribe and the owner are not one and the same person. Often, the information about the scribe - and sometimes about the owner as well - is supplemented by brief genealogical details of the person such as the names of his parents or even his grandparents, following Arabic expressions such as abīhu ('his father'), ismu abihi ('his father's name'), ummuhu ('his mother') and ismu ummihi ('mother's name'). Both the father's and mother's names may be preceded by the word ibn ('son').

With this information at hand, as limited as it is, one can start to locate the owner or the scribe of a manuscript and establish his identity. Moreover, by examining exactly which information is contained in the genealogical notes, we may also be able to unveil the approximate date of a manuscript's production. As Nikolay Dobronravin suggests in his analysis of colophons in the West African and nineteenth-century Brazilian manuscripts, '[e]arlier manuscripts often include both father and mother of the scribe ("son of X and Y") or even the name of his mother alone', while ' $[\mathrm{m}]$ ore recent manuscripts, especially those written in colonial and post-colonial West Africa, tend to be patrifocal' and therefore contain only the name of the scribe's father. ${ }^{9}$

\subsection{Places}

Among the total of thirty colophons examined in this study, at least fourteen give indications about the place of the manuscript's production. References to geographical locations in colophons may be given without any additional markers or they may also be introduced by terms such as ism balad ('name of the place'), fi balad ('in the place'), by the verb sakana ('to live', 'to dwell') or by the participle $k \bar{a}$ 'in ('being', 'existing', 'situated', 'located'). Quite often, indications of various places appear in conjunction with the location of the owner or scribe, and together they can provide modern scholars with relevant temporal and spatial information about the manuscript.

9 Dobronravin 2012: 92. 
In the following section, six case studies will be presented to exemplify what and how temporal and spatial information about OM manuscripts can be retrieved from their colophons. I will focus on names of various places found therein. Since personal names such as that of the scribe or the owner often appear together with place names, they will also be discussed.

\subsection{Case studies}

\subsubsection{Fugumba Seriyanke}

The first case study focuses on part of a composite manuscript in the collection kept by BnF. ${ }^{10}$ This part, shelf mark Ms Arabe 5586, fols. 1a-177a, is a copy of al-Risāla by Ibn Abī Zayd al-Qayrawani (d. 996). It is a treatise on Mālikī law, 'which has been used as a textbook for religious instructions throughout the Sahara and Western Sudan until today'. ${ }^{11} \mathrm{~A}$ few commentaries and glosses were added to the main text, but the most prominent paratextual element in this manuscript is a colophon at the end of the manuscript, which is arranged in three columns (Fig. 1). Although each column contains a different type of information, it is still not clear whether the layout was intentionally devised to mark the distribution of information.

The text of the first column consists of several formulae which ask God for forgiveness for the scribe, his family and all Muslims. It also states that the writing was finished on a Friday. ${ }^{12}$ The second column includes the name of the scribe and where he lived, and reads: ${ }^{13}$

10 The collection of West African manuscripts at $\mathrm{BnF}$ is known under the name of 'Bibliothèque 'Umarienne de Ségou', 'Bibliothèque d'Ahmadu' or 'Fonds Archinard' belonging to Ahmadu Sheku (Ahmad al-Kabir al-Madani), son of al-Hajj 'Umar, the religious leader of the Muslim Brotherhood Tidjaniya, who headed the Holy War between 1852 and 1864. Colonel Archinard captured this collection as a war trophy during the seizure of Ségou in 1890. He later transported the collection to Paris. See Brenner / Ghali / Mahibou 1985.

11 Ross 2011: 16.

12 The interpretation of the colophons hereafter, if not otherwise stated, is my own. When transcribing terms from Arabic, I have followed the conventions used in the transliteration guide of the Journal of Qur'anic Studies (JQS).

13 This is one of the two examples, along with BMT Ms. 2234, pp. 833-843, where the usage of additional diacritics was attested. The additional vowel diacritic sign (one dot below) was introduced to render the close-mid front vowel [e]. The character qaf used in Arabic for [q] probably has another reading and is used for rendering voiced velar plosive $[\mathrm{g}]$. 


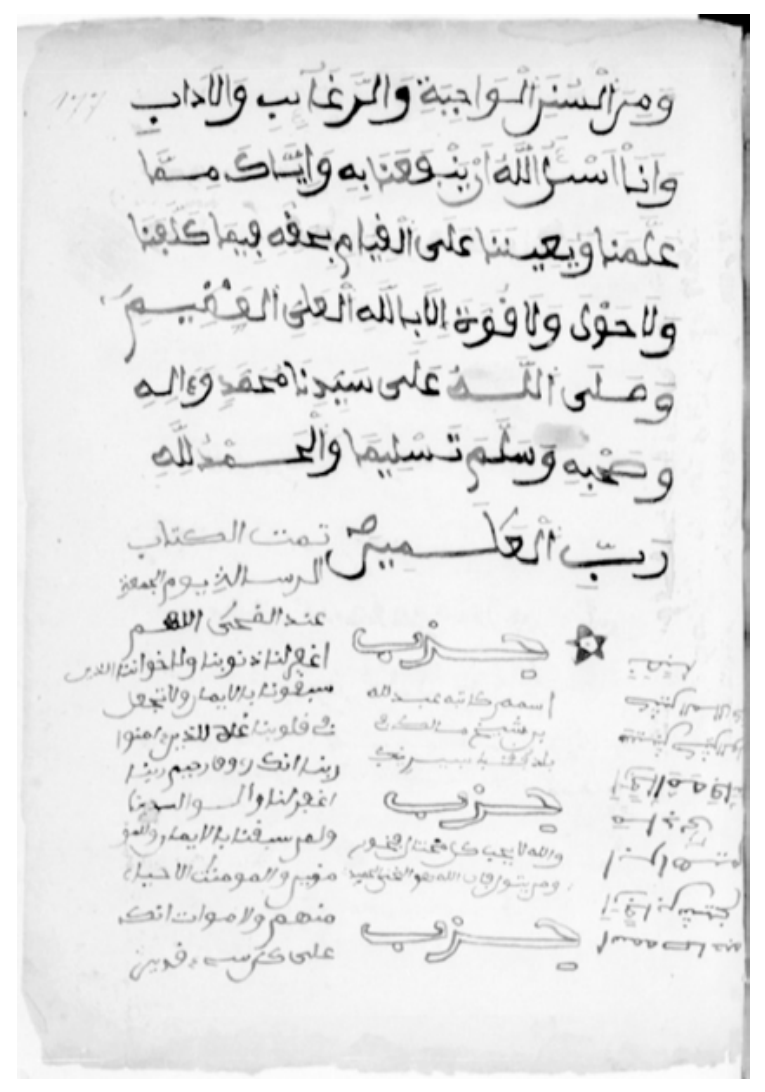

Fig. 1: The last page with the colophon from the copy of al-Risāla by Ibn Abī Zayd al-Qayrawani. Bibliothèque nationale de France, Paris, Ms Arabe 5586, fol. 177 a.

$$
\text { اسمم كاتبه عبدلله بس شيخ مالك جي بلد وُفنبا سبرِينك }
$$

[ismm kātbh 'bdllh bn shykh mālk fì bld fuqnbā seriyanke] ismu kātibuhu 'Abdallah bin Shaykh Mālik fì balad Fugumba Seriyanke.

The name of its scribe is Abdāllah ibn Shaykh Mālik from the place Fugumba Seriyanke. 
The place name provided in the colophon apparently refers to Fugumba, one of the nine provinces of Futa Jallon in Guinea ruled by Seriyanke, ${ }^{14}$ the oligarchic lineage or Islamic clerical lineage descendant of Fode ${ }^{15}$ Seri.

\subsubsection{Madina Findifeto}

As in the previous case, information about the owner of a manuscript and the place where the person lived can also be found in another manuscript which has two colophons. This document is part of a composite manuscript held in BULAC with the shelf mark Ms.Ara.219bis. An additional sheet, found inside the manuscript, bears a note written by Octave Houdas and reads "écritures du XVIII et du commencement du XIX ${ }^{\mathrm{e}}$ siècle. (Provient du Soudan)" ("writing of the eighteenth to early nineteenth century (of the Sudanic origin)"). ${ }^{16}$ The manuscript contains a religious poem on tawhīd called Jawāhir min al-kalām by Ibn Sulaym al-Awjilì (d. 1801/2). ${ }^{17}$ The main text is arranged with wide interlinear and marginal spaces and is enriched by glosses in Arabic and Soninke, some of which are written in black ink and some in brownish ink. ${ }^{18}$ The text is concluded by two short colophons.

14 Marty 1921: 28; Sow 1968: 8.

15 The word fóde/fóodee (or fódiye), both here and in several other manuscripts, refers to a title received by a person who can translate and comment on the Qur'an. See Creissels 2011: 64; Creissels / Jatta / Jobarteh 1982: 51; Diagana 2011: 57; Smeltzer 1997: 47; Sylla 2012: 311-312. According to Sanneh, a person becomes known as fóde either after the ceremony of investiture in his advanced studies or after accomplishing his studies as a student (Sanneh 1979). There is also an interpretation given by Giesing and Vydrine according to which the title fóde/fóodee may be acquired through the 'rite of expiation' reserved for those who cannot afford to perform the pilgrimage to Mecca (Giesing / Vydrine 2007: 366). Fode may also be used as a given name (Innes 1976: 298; Sanneh 1979).

16 Note that, most probably, Houdas employs the term "Sudan" to refer to the area of West Africa. 17 As identified by the first lines. See Hunwick 1995: 51. In the texts of the manuscript, the name of the author is written as Ibn Sulaym al-Awjali.

18 It seems safe to suggest that the glosses were written in at least two different hands in black and brownish ink respectively. The fact that some of them were probably added later than others is reflected in the position of glosses on the folio: those written in brown ink were added strictly between the lines of the main text, while those in black ink were placed in the blank spaces on the folio. Sometimes glosses in black were even written over the glosses in brown. 


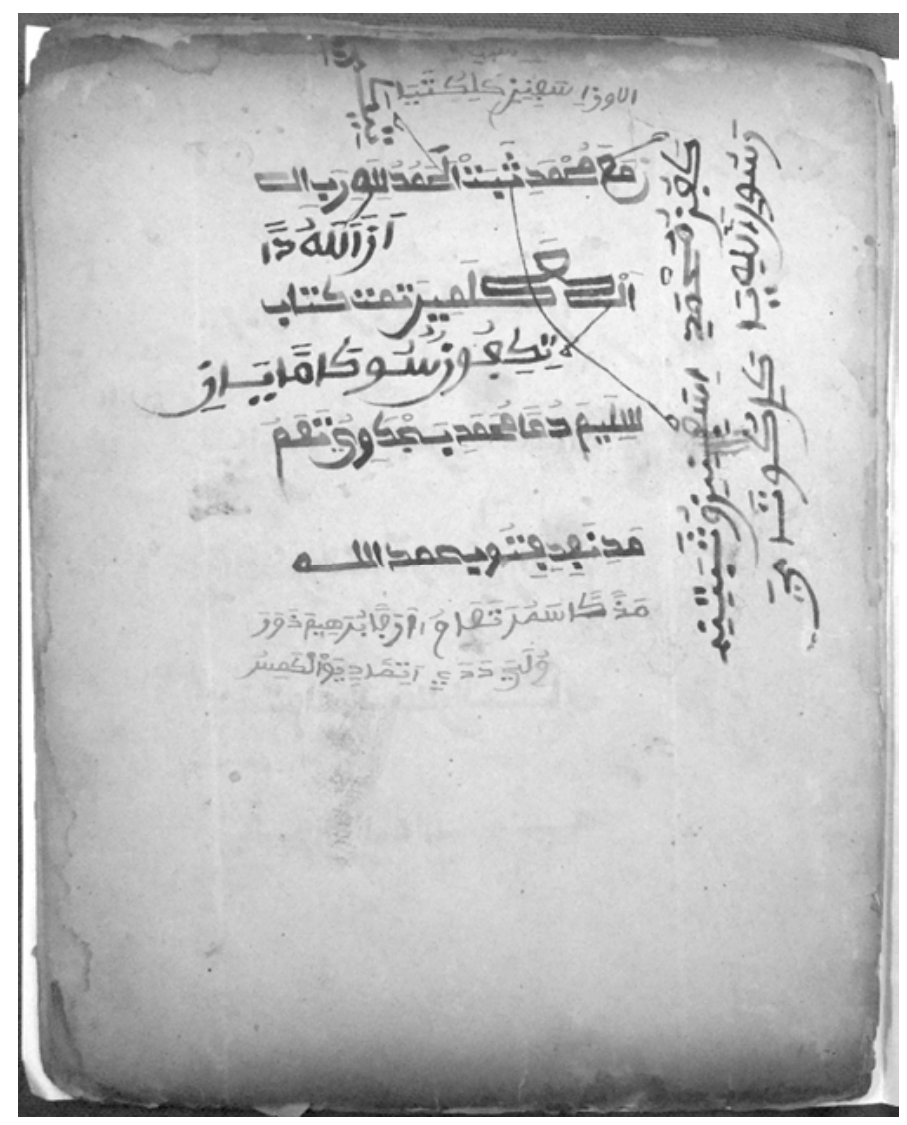

Fig. 2: The concluding lines of the poem on tawhīd called Jawāhir min al-kaläm by Ibn Sulaym al-Awjilī followed by two colophons. Bibliothèque Universitaire des Langues et Civilisations, Paris, Ms.Ara.219bis DP 18.

Interestingly, these two colophons seem to be composed in a vernacular language that differs from that of the glosses. On account of their linguistic features, I believe that these colophons were written in a language close to Mandinka (both colophons also contain several Arabic words). ${ }^{19}$

19 My hypothesis is based on the following evidence: the text of the colophon has the identification copula $m u$ and completive marker of transitive verbs ye, whereas glosses in Soninke have $n i$ and $d a$ respectively; focus marker $l e$ in the colophon and $y a$ in the glosses, etc. In my interpretation, I mark the words in Mandinka in bold. I mark the lexical tones of the Mandinka words in 
The first colophon, in black ink, was probably written by the same hand as that of the main text and it follows the layout of the main text, both having the same line length and letter size:

$$
\text { تمت كتاب سِلَيَ دُمًا مُحَمَدِ بَجْكَكِيُ تَعَمُ مَدِنَدِدِتُوُ بحمد لله }
$$

[tmt ktāb Silayma duman muḥamadi bajkawiyu ta'amu madinafidifitū biḥmd allh] tamat kitāb Sulayma dóoma Muhammadi Bajaka táa mu Madina Findifeto biḥamdulillah.

The small book by (ibn) Sulayma is completed. Property of Muhammad Bajaka, Madina Findifeto. Praise be to God. ${ }^{20}$

Directly below the first colophon there is another one written in brown ink in smaller letters:

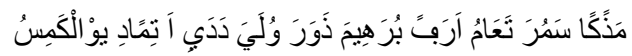

[madhinka samura t'ā̄ mu arafan burahìma dhawara wu laya dadayi à tinmandi yu alkamisu]

Majinka Samura táa mu arafạ Burahima Jawara wo le y'a dáda'a ye a tímmándi yaum alkamisa.

It belongs to Majinka Samura. Arafan Burahima Jawara prepared it. He finished it on Thursday. ${ }^{21}$

From these two colophons we learn that the copying of this manuscript was finished on a Thursday and the place of its production was probably Madina Findifeto. The linguistic features of the colophons suggest that the manuscript originates from somewhere in southern Senegal, the Gambia or Guinea-Bissau. In fact, the place name from the first colophon may correspond to two possible locations in the designated area. A locality called Findifeto is situated within the modern borders of the Gambia (Kantora, Upper River Region).$^{22}$ However, there is

\footnotetext{
accordance with the general principle used in Creissels 2011: the acute diacritics mark a high tone, while the absence of a diacritical sign corresponds to the low tone vowel.

20 The word dóoma in Mandinka means 'younger sibling'. However, in this case, Sulayma dóoma is likely to refer to a 'small' (i.e. short) version of a poem by ibn Sulaym.

21 The last two words are either distorted Arabic for yaumu-l-khāmisa (Thursday) or Arabic loans integrated into the Mandinka lexicon. The Mandinka verb dádaa means 'to make', 'to create', 'to prepare'.

22 Gamble 1996: 87 suggests that this name derives from the Portuguese expression fundo feito ('bottom struck') and it seems to be generally used to refer to places where shoals and rocks hindered sailing. Thus there could have been several different places that had the same name.
} 
also another place called Madina Findifeto in southern Senegal, as mentioned in the third part of the Pakao Book and in some oral traditions. ${ }^{23}$ In this example, madina, meaning 'town' in Arabic, is not just a generic term for 'town', but an integral part of the place name. It is very likely that since the word madina is written as one word together with the components that follow, the place name is Madina Findifeto. This part of BULAC Ms.Ara.219bis DI.8-18 probably originates from southern Senegal. ${ }^{24}$

\subsubsection{Suwarekunda}

Some spatial information pertaining to the manuscript can also be found in the colophon of part of the composite manuscript known as TCD MS 2689, which contains an anonymous work on cosmogony written on six folios (fols. 1a-6a).

The text of the colophon reads:

$$
\text { تمت هنا جي يوم احد من ييد كويتبها هو المصطبى سوار بس يرمغا سوار جي بلد سوار كند }
$$

[tmt hnā fi yum aḥd mn yyd kwytbhā hw al-mștf swār bn yrmghā swār fì bld swār knd] tamat hunā fi yaum ạ̣ad min yad kātibihā huwa al-Mușțafá Suware bin Yirimaghā Suware fi balad Suwarekunda.

Finished here on Sunday by the hand of its scribe, who is al-Mușțafa Suware ibn Yirimaghan Suware, in the place of Suwarekunda.

23 Shaffer 1975: 114 and 121; Schaffer 2003: 78-79. The Pakao Book, an eleven-page manuscript written in Arabic and Mandinka Ajami, records the history of the Pakao region in southern Senegal. 24 The specific layout where the main text is arranged in a relatively wide interlinear space. The abundance of explicative materials in the vernacular (glosses) suggests that the manuscript was

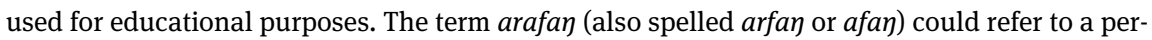
son who has finished Qur'anic school (Creissels 2011: 5) or it may refer to a student who has completed the initial stage of his studies (Gamble 2000: 61), but not yet reached the final level of his advanced Islamic studies (Sylla 2012: 312). Arafan could also be a proper name. 


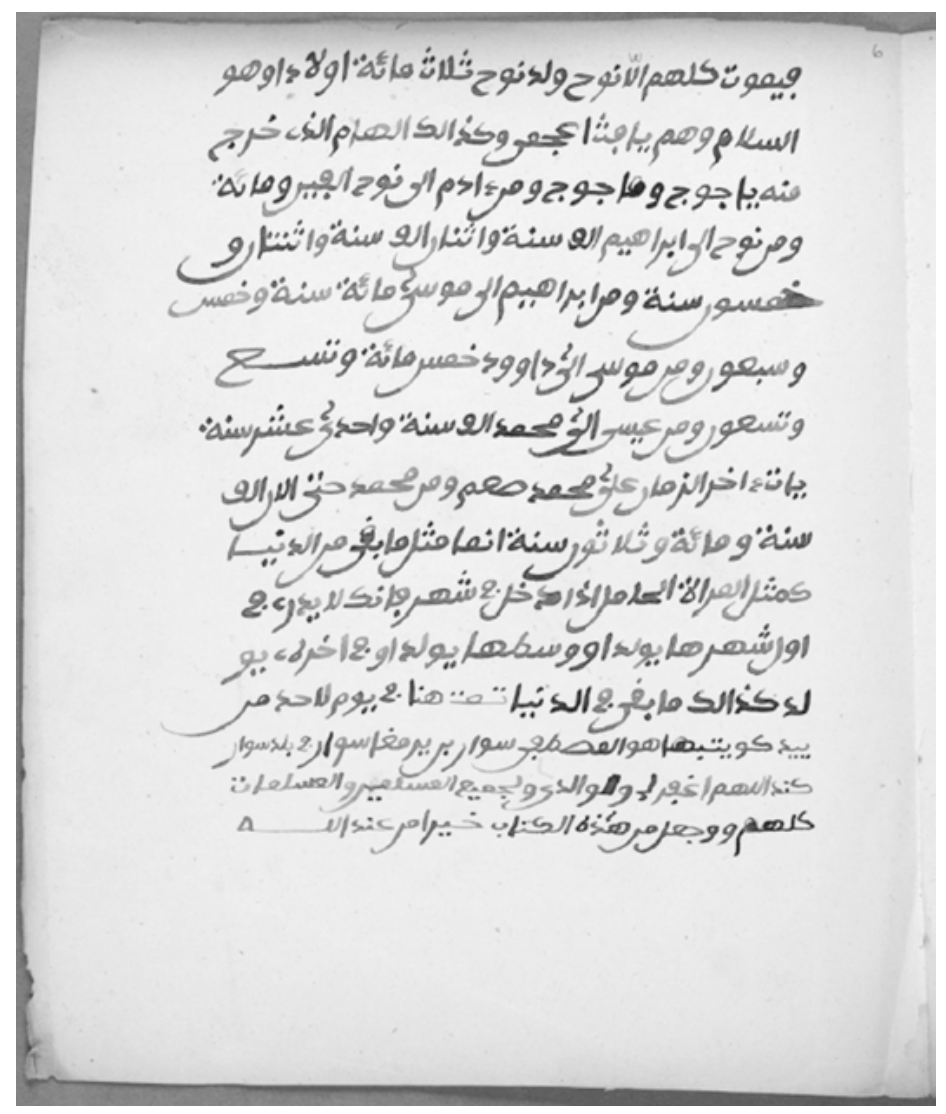

Fig. 3: The colophon at the end of the anonymous work on cosmogony. Library of Trinity College, Dublin, TCD MS 2689, fol. 6a.

The colophon states that this manuscript was copied by al-Mustafa Suware ibn Yirimaghan Suware, who was from a place called Suwarekunda. There are several references to Suwarekunda (or Souaré Counda) and one of them is mentioned in the studies written by Lamine Sanneh and Taslimaka Sylla respectively. ${ }^{25}$ Both authors mention Suwarekunda as the name of one of the clerical wards that form the Jakha settlement located in the Bambukhu region of eastern Senegal. ${ }^{26}$

25 Sanneh 1979: 19, 37; Sanneh 1989: 21; Sylla 2012: 111-112.

26 The word kúndaa can mean 'home', 'neighbourhood', ‘town' or 'region'. It is most commonly used in compound words in conjunction with family names, names of socio-professional categories, or names of ethnic groups. Here, however, it most probably refers to the part of Jakhaba 
Gamble and Quinn mention another place named Suwarekunda - an important scholarly centre in Badibu (also spelt 'Baddibu' or 'Badibbu'), the Gambia. ${ }^{27}$ Gamble also points out that although this place was once predominantly populated by Mandinka people, the original settlers, as it is evidenced in the name of the city, were the Jakhanke. ${ }^{28}$ Furthermore, in Lamin Sanneh's description of the life of al-Hajj Salim Gassama (Karamogo Ba), we find in the list of his students the name of Yirimaghan Suware, who lived in Badibu-Suwarekunda in the eighteenth century. ${ }^{29}$

\subsubsection{Mamakono}

A large manuscript in the collection of the BnF, shelf mark Ms Arabe 5657, contains three different texts with glosses in OM. The first text, on fols. $1 \mathrm{a}-28 \mathrm{~b}$, is a copy of the poem Dalì al-qā'id li-kashf asār șifāt al-wāḥid by Ibn Sulaym al-Awjilì. Given the fact that Ibn Sulaym al-Awjili died in 1801/2 and this manuscript was acquired in Ségou in 1890, it should be safe to suggest that it was produced sometime in the nineteenth century before 1890. Apart from the glosses written by different hands, the text also contains a colophon outlined by a simple geometrical decoration (Fig. 4). The text of the colophon reads as follows: ${ }^{30}$

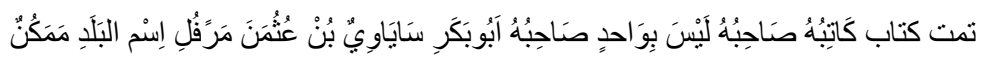

[tmt ktāb kātibuhu șāḥibuhu laysa biwaḥdin șāḥibuhu abūbakari sāyāwiyun bun 'uthumana maranquli ism albaladi mamakunun]

tamat kitāb kātibuhu șāḥibuhu laysa biwaḥidin șāḥibuhu Abūbakari Sāyāwiyun bin 'Uthmana Maranquli ism al-baladi Mamakono.

The book is completed. Its scribe and its owner are not the same person. Its owner is Abūbakari Sāyāwiyun ibn 'Uthmana Marankuli. The name of the place is Mamakono.

inhabited by members of the Suware family. The family is known because of al-Hajj Salim Suware, a fifteenth-century scholar who is considered to have established a pedagogical tradition among the Jakhanke and founded the town of Jakhaba. See Wilks 2000: 96-98.

27 Quinn 1972: 100 and passim; Gamble 1999: 107.

28 Gamble 1999: 106.

29 Sanneh 1979: 121.

30 I have included the full text of the colophon here (the text was written in small characters and placed in a decorative frame). The last line is crossed out and thus difficult to read. 


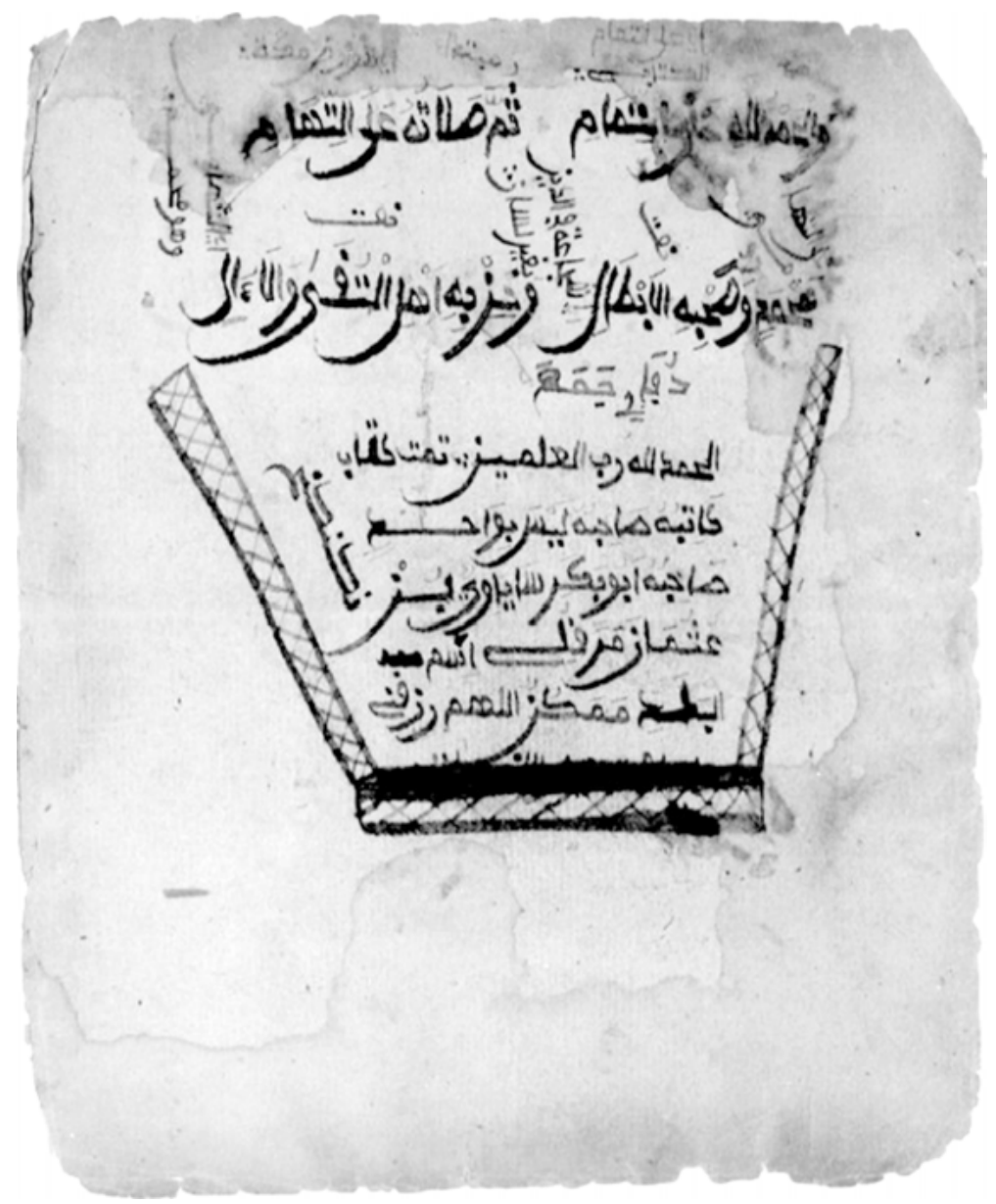

Fig. 4: The poem on the attributes of God as evidenced by the colophon on the last page was owned by Abubakar Sāyāwiyi. Bibliothèque nationale de France, Paris, Ms Arabe 5657, fol. $28 \mathrm{~b}$.

In this colophon, we can see that the name of the owner was Abūbakar Sāyāwiyun $^{31}$ ibn 'Uthman Maraquli from Mamakono and that he was not the one who actually produced the manuscript.

31 In these three examples and in several other colophons, the family name of the owner has the ending -wiyu or -wiyun. This is probably the nisba suffix forming an adjective, which indicate the origin or social affiliation of a person. In the colophon of BMT Ms 2234 (pages 833-843), the 
The second text in the manuscript is written on fols. $36 \mathrm{a}-84 \mathrm{~b}$. It contains the

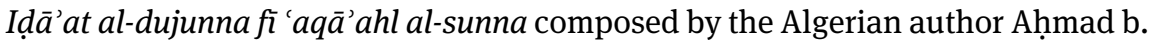
Muḥammad al-Maqqārī (d. 1632) (Fig. 5).

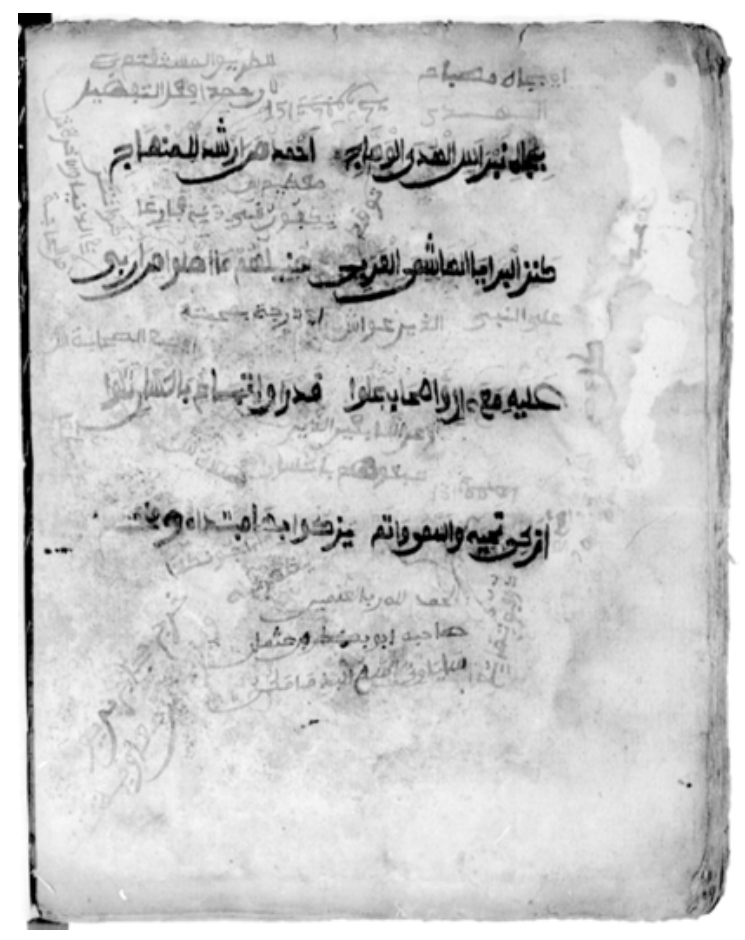

Fig. 5: The last page of the work on belief from the library of a certain West African scholar named Abubakar ibn 'Uthman Sāyāwiyi. Bibliothèque nationale de France, Paris, Ms Arabe 5657, fol. 84b.

family name of the owner ends in -ji: 'kātbh füdey yula wa ammihi mā kale w abīhu dāwuwdu ibn shykh dunbā fudi dunbuyā jiyy' (kātibuhu Fode Yola wa ummuhu Mā Kale wa abuhu Dāwudu ibn Seikh Dunbā Fode Dunbuyaji, which translates as 'its scribe Fode Yola and his mother Mā Kale and his father Dāwudu ibn Sheikh Dunba Fode Dumbiyaji'). The meaning of this element is still not known. The name Sāyā can be read in various ways because some characters of the Arabic alphabet (or a combination of several characters) could receive an additional value to designate the Mande sounds absent in Arabic. In the glosses, the Arabic letter $y a$ is used to represent the palatal nasal [n] with a respective vowel. The family name of the author could thus be read as Sanaa. According to various sources, the family name Sajaa (or Sanan) corresponds to the family name Keita. See Gamble 1996: 6b; Guesing / Vydrine 2007: 381; Innes 1974: 130; Schaffer 2003: 98 and passim. 
As in the previous example, the main text here is accompanied by a number of glosses in OM placed in the interlinear and marginal space and written in a style close to that of the main text. The hand used to write the colophon resembles the script of the glosses and is in small letters:

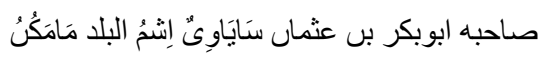

[șāhbh abūbkr bn 'thmān sāyāwiyun ishmu albld māmakunu] șāhibuhu Abūbakar bin 'Uthmān Sāyāwiyun ismu al-balad Māmakono.

The owner is Abūbakar ibn 'Uthmān Sāyāwiyun. The name of the place is Māmakono.

It is evident that the personal name and place name indicated in the colophon are the same as in the previous text from manuscript Ms Arabe 5657.

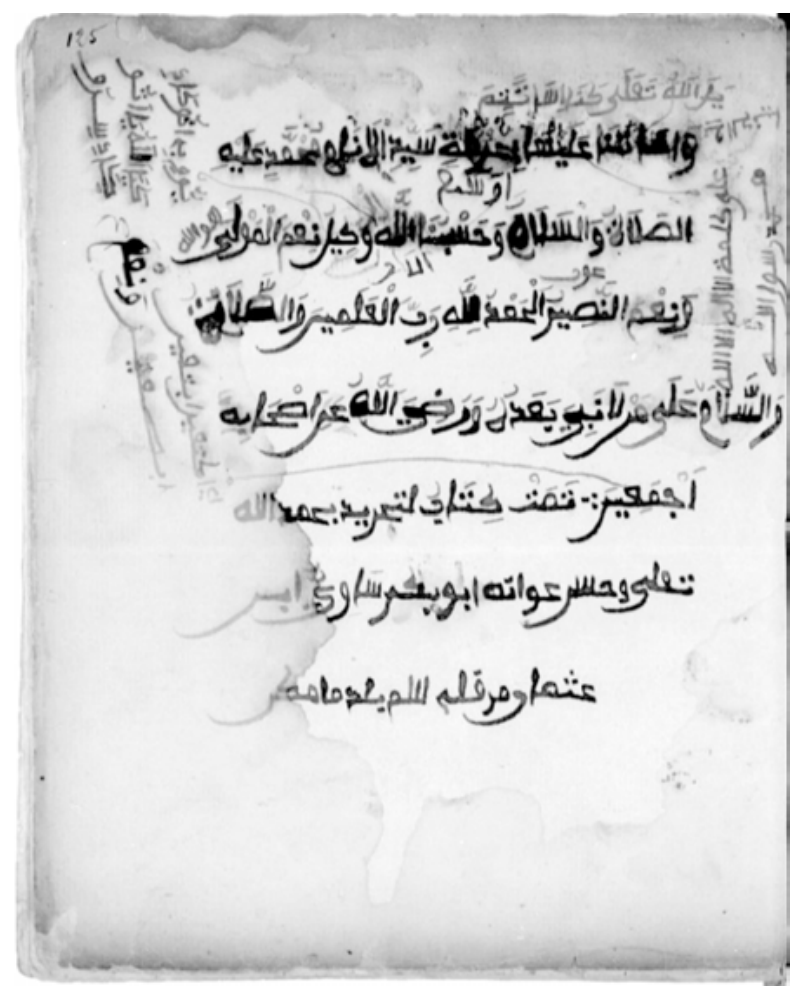

Fig. 6: The commentary on the attributes of God ending with the colophon, which indicates the ownership and provides a place name. Bibliothèque nationale de France, Paris, Ms Arabe 5657, fol. 125a. 
The third text in this manuscript, on fols. 109b-125a, bears the title Tajrì fi kalimat al-tawhìd and is a commentary on the attributes of God by Ahmad b. Muhammad al-Ghazālī (d. 1123). The main text is complemented by marginal translations from Arabic into the vernacular. The colophon is written in the same script as the main text and the lines become narrower as they progress to the bottom of the folio (Fig. 6).

Here again, we find an attestation that the manuscript was owned by the same Abubakar Sāyāwiyi ibn 'Uthman Maraquli, who is said to have lived in a place called Mamakono:

$$
\text { تمت كتاب التجريد بحمد الله تعالى وحسن عو انه ابوبكر ساوِيٌ ابس عثمان مرفلى سم بلد مامك }
$$

[tmt ktāb altjrīd bḥmd allh t'ālá w ḥsn 'wānh abūkbr sāwiyun bn 'thmān mrqly sm bld māmkn] tamat kitāb al-tajrīd biḥamdu lillahi t'ālá wa ḥasani 'awānahi Abūbakar Sā [yā]wiyun ibn 'Uthman Maraquli ism balad Mamakono.

The book "Tajrīd" is completed. Praise be to God, the sublime and infinitely good. Abūbakar Sāyāwiyun ibn 'Uthmām Maraquli. The name of the place is Māmakono.

The subject matter of all three texts refers to belief (tawhìd). The texts probably all once belonged to the library of the West African scholar Abūbakar Sāyāwiyun, because the same name appears in each of their colophons. Although no information is available as to who the scribe was, considering that the hands are quite similar to each other, one cannot exclude the possibility that the same person transcribed all three texts. If this is true, then they may all be dated to the nineteenth century. However, a more detailed palaeographic examination is required to prove this point, especially considering the poor quality of the pictures available for this study.

As for their place of origin, there are several possible places that Mamakono might refer to. From Hecquart's travel account from the mid-nineteenth century, we learn that Mamakono was the name of a village situated not far from Kedougou in eastern Senegal, close to the Malian border. ${ }^{32}$ Another possible candidate is a village mentioned in the Pakao Book. The first text in this work mentions a certain place called Mamakonoba or Mașakonoba. ${ }^{33}$ A village called Mākonoba

32 Gessain 1963: 29.

33 Part 1 of the Pakao Book lists the first twenty-five villages in Pakao that had mosques. It also provides names of imams for whom these mosques were built as well as names of the founders of the village. It states that Mamakonoba or Mașakonoba (as it is not clearly written in the original manuscript and the second character could be read as șad or mim - both interpretations are 
appears in the third text. Matthew Schaffer argues that the same village is mentioned despite variations in spelling in the first and third parts of the Pakao Book, and its exact name should be Mankonoba. ${ }^{34}$

The linguistic peculiarities of the glosses in the three texts in this manuscript possibly point to the fact that the Soninke language found in the glosses was influenced by Mandinka. ${ }^{35}$ If this assumption is correct, the manuscripts must have originated from Mamakono (or Mankonoba) in Pakao, southern Senegal, unless there are other settlements with the same name in the Mandinka-speaking area outside Pakao.

\subsubsection{Bani Isra'il}

The fact that a place name in a colophon may correspond to several possible locations on a map can also be observed in other OM manuscripts - this is the case for another manuscript from BULAC with the shelf mark Ms.Ara.112b, for instance. ${ }^{36}$ The colophon is written separately from the main text on the folio at the

possible) was founded by a certain Fode Bukari Djaa Sāyā, who came from Kantora. See Shaffer 1975: 118; Vydrine 1998: 54.

34 Schaffer 1975: 97. According to Schaffer's investigation among the elders of the Pakao region, the manuscript was most probably copied by two different scribes. This could be the reason why the name of the village is spelt differently. There are three legends explaining the origin of the village's name in Schaffer 2003: 159-168. The elders of the village say that the name Mamakono is derived from a founder's honorific nickname - Mama - as he was named after his grandfather (maama/mama means 'grandparent' in Mandinka). According to the legend, the name 'Mamakono' then transformed into 'Mankonoba'. The same spelling is used to mark the village on the modern map.

35 The main distinctive feature is the loss of the voiceless uvular fricative $[\mathrm{x}]$ in the intervocalic position attested in several instances in all three texts in this manuscript. For example, in Iḍa at al-dujunna fi 'aqā'ahl al-sunna fol. 41b, we find glosses with the word naaminte, which corresponds to modern Soninke naxaminte, 'mixed'. Some other examples: fol.44a, the gloss waati vs. modern Soninke wax $a$ ti, 'time'; fol. $62 \mathrm{~b}$, the gloss maagenmu vs. modern Soninke maxagenmu, 'agreement', 'accord'.

36 This manuscript contains fragments of several texts. It is a loose-leaf manuscript and is wrapped in a traditional cover made of cloth. The most complete and voluminous text is the famous exegetical text Tafsīr al-Jalālayn composed by two Egyptians scholars, Jalāl al-Dīn Muhammad al-Maḥallī (d. 1459) and Jalālal-Dīn 'Abd al-Raḥmān al-Suyūṭī (d. 1505). This part consists of about four hundred folios. The text is acephalous and starts from sura Maryam (Q.19). It is written in light brown and red ink, and the same red colour is also used for highlighting quotations from the Qur'an. 
end of the manuscript and states that the writing was finished by the scribe and the owner, al-Hajj Drame, living in Bani Isra'il (Fig. 7):

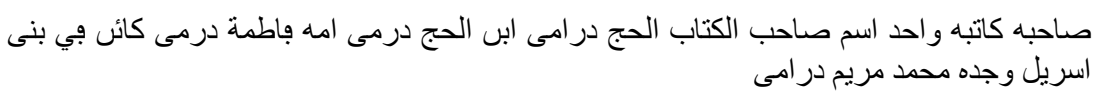

[șāḥbh kātbh wāḥd ism șāḥhh alktāb alḥj drāmy ibn alḥj drmy umh fāṭmt drmy kā'in fì bny israìl wḥdh mḥmd mrym drāmy]

sāhibuhu kātibuhu waḥidu sāhibu al-kitāb al-Hajj Darāme ibn al-Hajj Darame ka'in fi Bani Isra'il wa jaddahi Muhammad Maryam Darāme.

Its owner and its scribe are the same person. The owner of the book is al-Hajj Darāme ibn al-Hajj Darame, who lives in Bani Isra'il, and the name of his grandfather is Muhammad Maryam Darame.

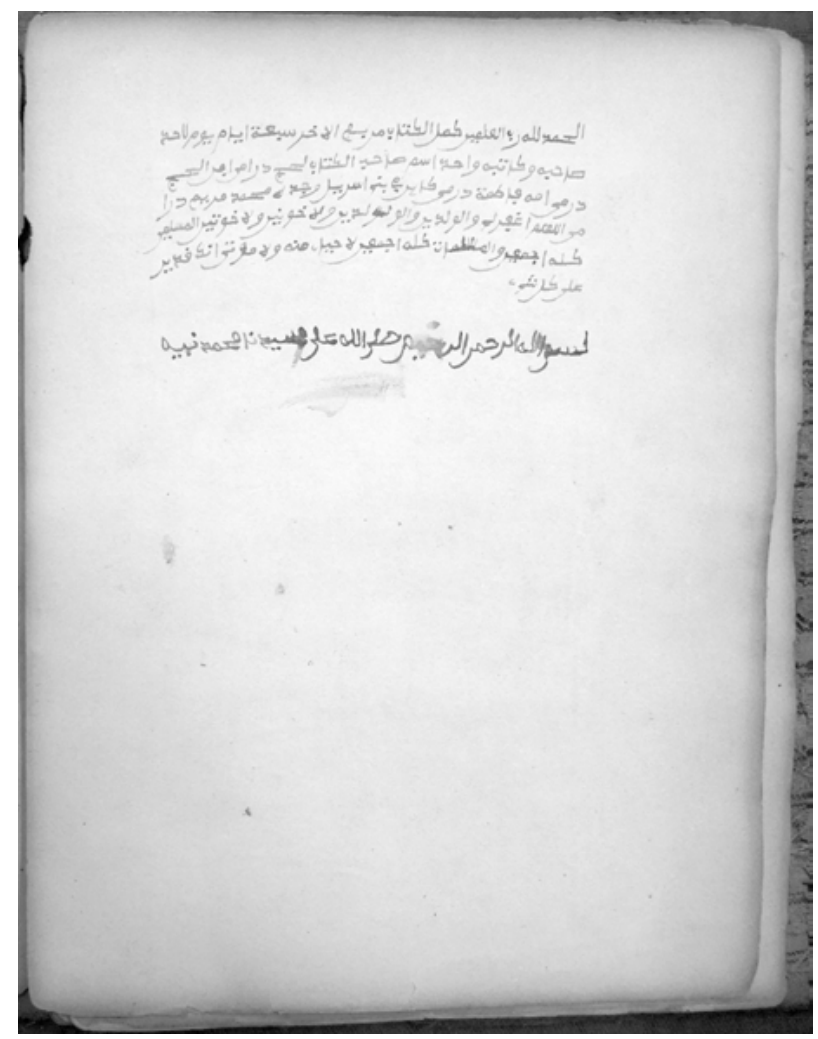

Fig. 7: The colophon placed separately at the end of a copy of the famous exegetical text Tafsir al-Jalälayn. Bibliothèque Universitaire des Langues et Civilisations, Paris, Ms.Ara.112b. 
Various sources suggest that Bani Isra'il is a major scholarly centre of Jakhanke clerics located in the Bundu (Boundou) region of eastern Senegal. ${ }^{37}$ Another place with the same name, situated in the modern Casamance, Sedhiou region in southern Senegal, is reported in the third part of the Pakao Book. ${ }^{38}$ In addition, there is also a place named Bani Isra'il in Kantora in the Gambia. ${ }^{39}$

\subsubsection{Dar Silame (Dar-as-Salam)}

In fact, many manuscripts contain some spatial information which cannot be easily identified, as in the case of manuscript MS 2179 in a collection kept by Trinity College, Dublin (TCD). This is a copy of al-Quayrawani's al-Risāla, which consists of a set of unbound pages wrapped in a leather cover. ${ }^{40} \mathrm{~A}$ colophon written over six lines, shaped in a rectangular form, is appended to the end of the manuscript. It is rendered in letters smaller than those of the main text and only the family name of the owner is vocalised (Fig. 8).

37 See, among others, Marty 1917; Sanneh 1979 and 1989; Smith 1965: 233; Sylla 2012: 154-160. Bonnel de Mézières suggested that this place name Bani Isra'il ('Children of Israel', 'Israelites') indicates that the founders of the town were of Jewish origin. Smith (1965) rejected this theory, however. Gamble (1996) also denies any relationship between the place name and Jewish people, but considers this as an argument in favour of the adherence of founders to the Islamic religion. Sylla (2012: 164) supposes that the place could have been named after the seventeenth sura of the Qur'an. Tal Tamari (p.c.) pointed out that this tradition of Israelite origin is shared by numerous groups, especially those with a Fulbe and Soninke background. I am also grateful to Tal Tamari for referring me to Delafosse (1913) and Bello (1951), who mention this genealogical tradition in West Africa. Therefore it should not be ruled out that there were other places that had Bani Isara'ila as a toponym.

38 Schaffer 1975: 121; 2003: 95; Vydrine 1998: 61.

39 Gamble 1996: 17 and passim.

40 It seems that at least two people were involved in the copying process since different hands and inks can be observed. The first part of the text is written in dark blackish-brown ink and the letters appear angular. Starting from fol. 40a, the hand changes and letters tend to be increasingly rounded. Annotations in the form of interlinear glosses provide explanations on the main text. Voluminous marginal commentaries in Arabic inform the reader about the history of the Caliphate, an Islamic cosmology, and give examples of West African calculation techniques. See Dobronravin / Gittins 2013. 


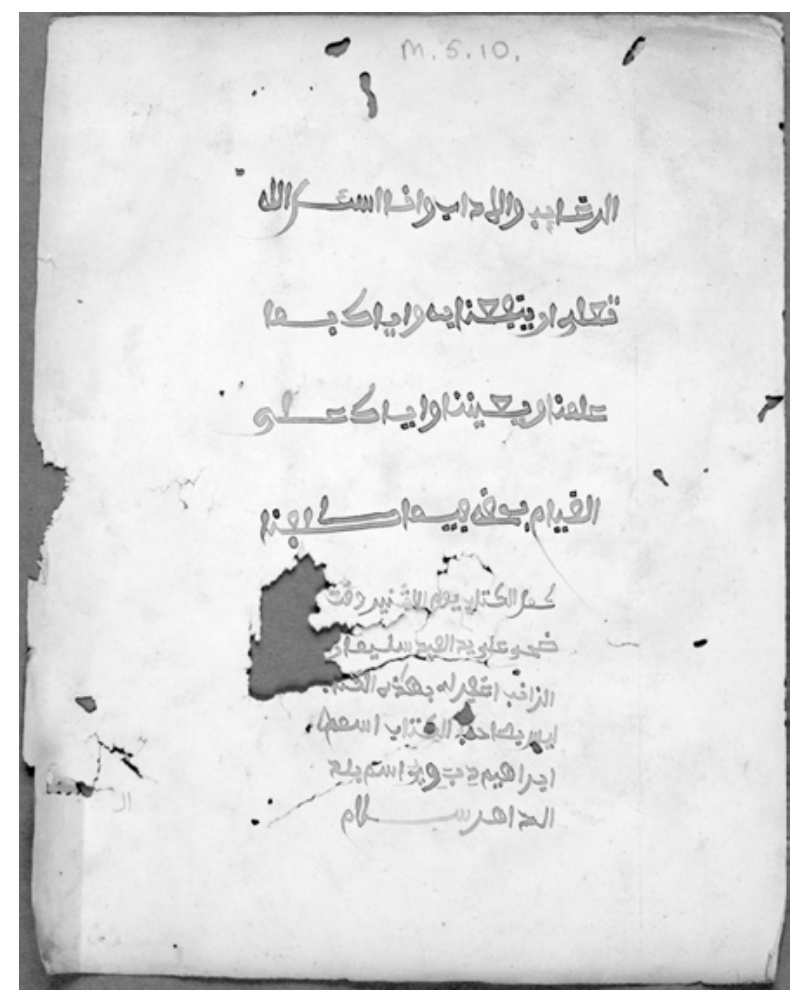

Fig. 8: A copy of al-Risāla appended by a six-line rectangular colophon. Library of Trinity College, Dublin, TCD MS 2179, fol. 274b.

The colophon states that the text of the manuscript was copied by a man called Suleyman and that it was finished on a Monday before noon. The owner is a different person called Ibrahim Dibawiyu. The place named Dahr Salam also appears in the colophon: ${ }^{41}$

$$
\text { الكاتب ليس بصاحب الكتاب اسمه ابر هيم دِبَ وِيُ اسم بلد الداهر سلام }
$$

[alkatb lys bṣāḥb alktāb ismh ibrhym dibawiyu ism bld aldāhr slām] al-kātib laysa biṣāhịb al-kitāb ismuhu ibrahīm Dibawiyu ism balad al-Dāhr Salām.

The scribe is not the owner of the book. The [owner's] name is Ibrahim Dibawiyu. The name of the place is Dāhr Salām.

41 Only lines 3-6 of the colophon are given here. 
As for the aforementioned examples, there are a number of places to which Dahr Salam - apparently derived from Dar-as-Salam ('land', 'place of peace') and its variants, such as Darsilame, Dassilame or Darusalam - may refer. They could be in Senegal, the Gambia ${ }^{42}$ or even other West African countries. There are no other details that could help identify a specific geographic location. However, as discussed in section 2.5.4, the linguistic features of the glosses suggest that Dahr Salam in this manuscript must be situated somewhere within the Mandinkaspeaking area of West Africa. ${ }^{43}$

\section{Indications of the time of completion}

The time of copying is recorded in thirteen manuscripts out of the total of thirty I have examined for this study. However, most of them provide very limited information about the time of their production, as in eleven manuscripts only the day of the week and the time of the day is mentioned without specifying which week, month or year is actually meant.

Some temporal information is rather obscure to our present knowledge of OM manuscripts. For instance, in JRL 780 [825], fols. 1a-12b and TCD 3499, fols. 160b-296a, possible temporal names are given after the expression 'name of time' (ism zamān) (Figs. 9 \& 10).

42 See, for example, Schaffer 1975: 97, who mentions that Dar Silame is one of the most important villages in Pakao. See also Schaffer 2003: 5 and passim. In Gamble 2006: 90 and passim, Dar Silame appears as the name of a village in Central Kombo.

43 The glosses in this manuscript also feature lenition of the voiceless uvular fricative [x], which provides more evidence of the Mandinka influence on Soninke. Moreover, there is an additional layer of the glosses which represents translations of the Soninke words into Mandinka. These translations are written after the Arabic words fi kalāmina ('in our words', 'in our language') and they give us insights into the identity of the scribes and support the assumption that Soninke was not the scribes' first language. The linguistic peculiarities of the glosses will be addressed in more detail in the proceedings of the Old Mande Research Network (OMRN) sessions. 

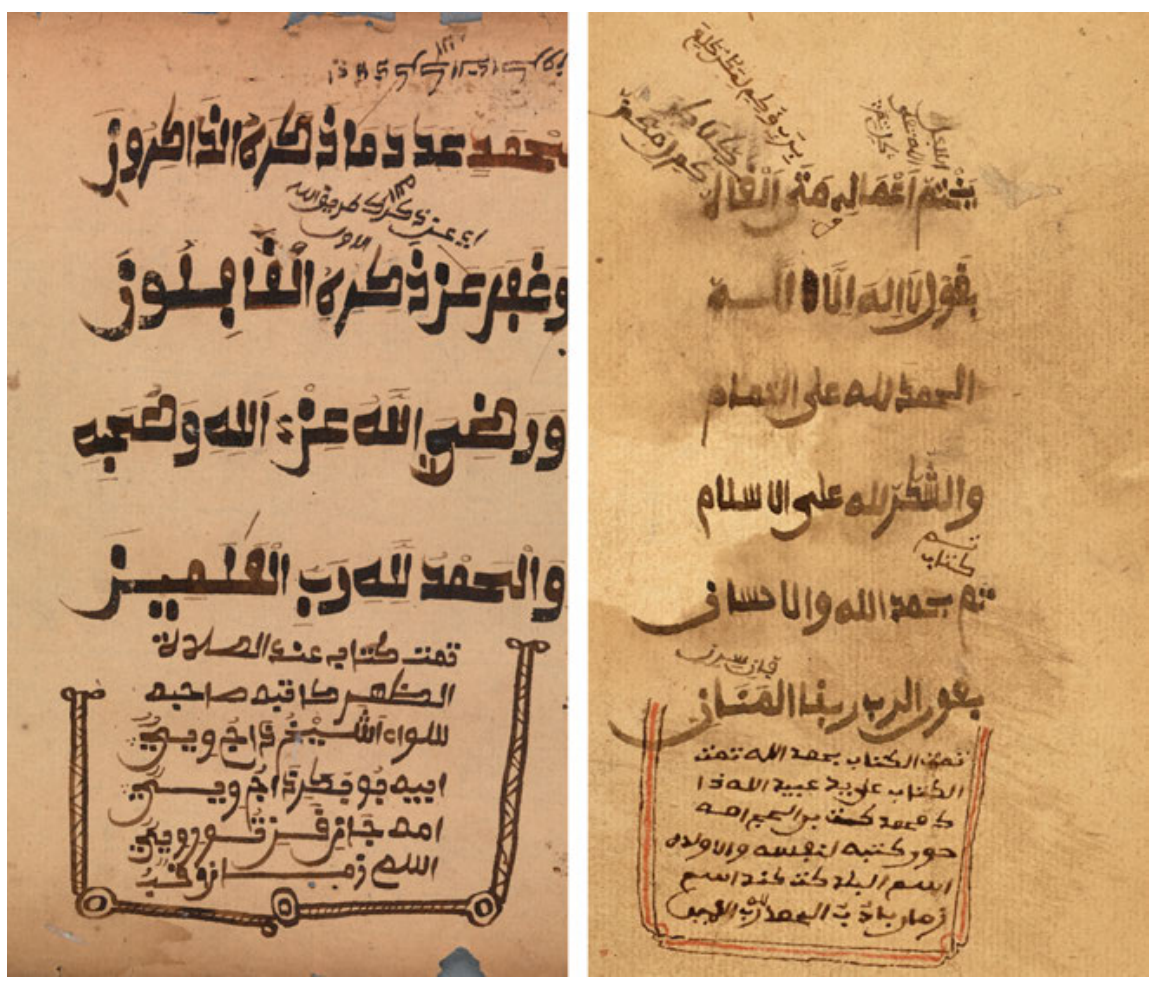

Figs. 9 \& 10: Two colophons recording dates in an unknown format, which appears after the words ism zamān ('name of time'). Library of Trinity College, Dublin, TCD MS 3499, fol. 296a and Rylands Library, Manchester, Ms 780 [825], fol. 12b.

The colophon on TCD MS 3499, fol. 296a states:

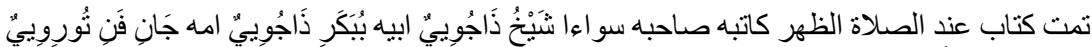

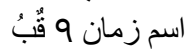

[tmt ktāb 'nd alṣlāt alzahr kātbh șāhhbh swā' skaykhu dhājuwuyun abyh bubakari dhājuwiyun umh jāni qani tūriwiyun]

tamat kitāb inda al-ṣalāh al-ẓuhr kātibuhu șāḥibuhu sawā' Shaykhu Jājuwiyun abihi Bubakari Jājuwiyun ummihi Jāne Qani Tūrewīyun ism zamān Qunbu.

The book was completed at the time of afternoon prayer. Its scribe and its owner are both Sheikh Jajuwiyun, his father is Bubakar Jajuwiyun, his mother is Jane Qani Turewiyun, and the name of the time is Qunbu. 
The colophon on JRL Ms780 [825], fol. 12b reads:

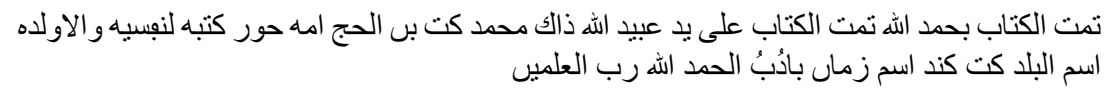

[tmt alktāb bhmd allh tmt alktāb 'lá yd 'byd allh dhāk mḥmd kt bn alhj umh hwr ktbh lnfsh walāwldh ism albld kt knd ism zmān bādubu ilhmd llh rb al'lmyn

tamat kitāb bihamdu lillahi tamat al-kitāb 'alá yad 'abd allah zāka muhammad [kt] bin alHajj ummahu [hwr] katabahu linafsihi wa al-awlādihi ism bilad [kt knd] ism zamān Bādubu al-ḥamdu lillahi rabba al-'alāmìn.

The book is completed - praise be to God. The book was completed by the hand of God's servant, that is, Muhammad [kt] ibn al-Hajj, his mother [hwr], written for himself and his sons. The name of the place is [kt knd, and the] name of the time is Bādubu.

The words that follow 'name of time', Qunbu and Bādubu, do not seem to be chronograms encoded in abjad. ${ }^{44}$ Neither could I recognize in these words any name of a month or a season. It is much more likely that the words written after the expression 'name of time' are not Arabic or numerical encoding. This is because (1) they are vocalised and (2) the words $Q u n b u^{45}$ and Bādubu quite plausibly evoke chronologically and regionally appropriate names of specific epochs of two West African kingdoms of Kombo and Badibu respectively. ${ }^{46}$ It is possible that these words do not only refer to temporal information, but also to the geographical scope of these kingdoms. ${ }^{47}$

44 Abjad is an alphanumerical system in which a numeral value is assigned to each letter of the Arabic script.

45 It is possible that the Arabic $q$ was used here to indicate the quality of the following vowel. If this is really the case, the word following 'name of the time' can be read as Kombo.

46 Badibu and Kombo (or Combo) are two Mandinka kingdoms, which existed on the territory of what is now the Gambia until the nineteenth century. See, for example, Quinn 1972: 30 and passim.

47 Tal Tamari (p.c.) has suggested two interpretations for the term zamān as follows. (1) The word zamān could be interpreted as the Manding term jamana, 'country', which in some contexts has the more specialised meaning of 'state' or 'large chiefdom'. Going by this interpretation, the word balad in Ms. 780 [825], fol. 12b would designate a smaller locality within a country. (2) An alternative hypothesis suggested by Tal Tamari (email dated 5.6.2015) is that "the Arabic word zamān (also used with adapted pronunciation in Manding) is to be understood as "reign" and by extension "realm". While these may not be the proper meanings of this Arabic term, they are ones that may be easily inferred from one of its most common usages ("in the times - i.e. the reign or rule - of so-and-so"). Such a usage would have been particularly appropriate in the context of the Mandinka kingdoms, each of which had its own [particular] dynasty'. I am also grateful to Tal Tamari for drawing my attention to the missionary material in the Special 


\section{Language of paratexts}

In addition to explicit mention of temporal and spatial information, linguistic features of paratexts written in vernaculars can also help us locate OM manuscripts. This is the case for both colophons and glosses. However, the latter category stands out even more prominently as a means for our investigation, since colophons, as we have mentioned above, are often missing or incomplete in the manuscripts at our disposal. In such cases, an investigation of the language may be crucial for proper identification of a manuscript's linguistic and geographical origin. Due to the fact that linguistic features of the annotations have not been taken into consideration, OM manuscripts are usually listed under the general category of Arabic, African or Maghribi manuscripts in many library catalogues. The linguistic properties of glosses and colophons in this case allow modern scholars to classify those manuscripts as part of the OM manuscript culture.

In the corpus of thirty manuscripts examined here, at least two West African languages, Soninke and Mandinka, can be identified in colophons and glosses. Most colophons in the OM manuscripts are written in Arabic. In several cases, however, some words or phrases are composed in the vernacular, in particular annotated manuscripts and manuscripts containing medicinal and talismanic texts found in several composite volumes from Trinity College Library in Dublin, Bibliothèque Universitaire des Langues et Civilisations in Paris, etc. Apart from personal and place names in colophons, other information is also written in languages other than Arabic. This often happens when days of the week are recorded. For instance, in two different places of TCD MS 3499, a manuscript owned by a certain Abūbakar Jāju, one can read [aramisalun] (araamísa lún, 'Thursday') on fol. 42b, and [talatalu ${ }^{\mathrm{n}}$ (taláata lún, 'Tuesday') on fol. 130b. Frequently, as it is the case in five manuscripts in our corpus, the name of the owner of a manuscript is followed by [tā mu] (in a different spelling [tamu] or [ta'amu]) táa mu, meaning 'part' or 'property of', 'that of', 'that belongs to'. Also genealogical information on the scribe or the owner is sometimes written in the vernacular, as in [a fmā] (a faama, 'his father') in the manuscript BULAC Ms.Ara.165a DI.246-250

Collection of the SOAS library that goes back to the 1830s. This material that comprises two gospels translated into Mandinka with the collaboration of local Muslim scholars - one in Latinbased script, the other in Arabic-based script - suggests that the term zamān 'seems to connote an area considered as a political (perhaps especially dynastic) unit.' (Tal Tamari, email dated 15.7.2015). To further explore this problem it will be necessary to compare these missionary documents with the contemporaneous OM manuscripts. 
and [a fā t] (a faa tóo, 'his father's name') in MAAO AF14722 fols. 5ab and 102a174a.

In these manuscripts, the language used for writing the colophon seems to be different from the language of the glosses and could tentatively be identified as Mandinka. Here is an example from a composite volume, BULAC Ms.Ara.219bis, which contains a fragment of an unidentified poem, DI.72-74. The colophon composed in Mandinka states the day of completion and the ownership of the manuscript. It reads as follows:

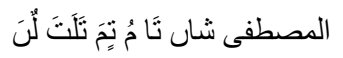

[almușțafa shāni tāmu tinma talata lunna]

al-Muștafá Saane táa mu tímma taláata lún na.

It belongs to al-Muștafa Saane. Completed on Tuesday.

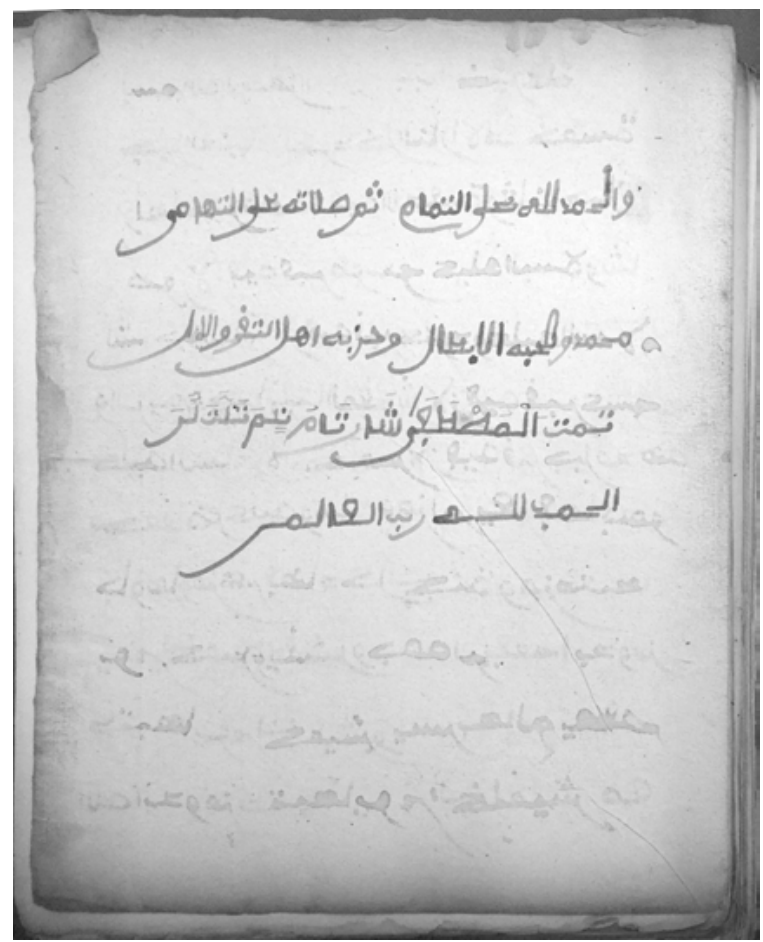

Fig. 11: The colophon, written in Mandinka, follows an unidentified poem and indicates when the copying was completed. Fragmentary part of the manuscript kept at the Bibliothèque Universitaire des Langues et Civilisations, Paris, Ms.Ara.219bis DI.74. 
The presence of Mandinka words in the colophon suggests that these manuscripts were produced, or at least once used, in the Mandinka-speaking area of modern southern Senegal, the Gambia and Guinea-Bissau.

Vernaculars are also used in JRL 780 [825], fols. 1a-12b. On its first folio, four glosses are written to translate the author's name, 'Abd al-Rahmān (lit. 'servant of the all merciful'). Two of them are written upside-down in Soninke in brown ink below the line, while the other two, which are written in black ink, could be identified as a translation in Mandinka (Fig. 12).
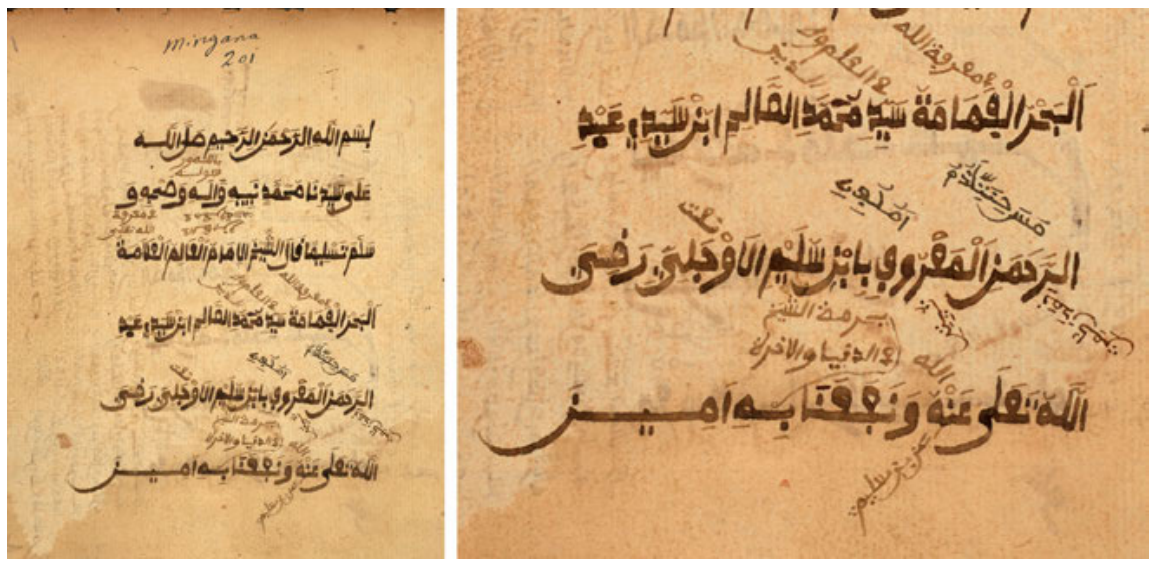

Fig. 12: Glosses written in two different West African languages: Soninke and Mandinka. John Rylands Library, Manchester, Ms 780 [825], fol. 1a.

\begin{tabular}{|c|c|c|c|}
\hline Text & Transliteration & Transcription & Interpretation \\
\hline \multicolumn{4}{|l|}{$\begin{array}{l}\text { Upper line } \\
\text { (Mandinka) }\end{array}$} \\
\hline مَسَ حِنَتَلْمُ & $\begin{array}{l}\text { masa hinat- } \\
\text { tiladhumu }\end{array}$ & mansa híinántee la jon mu & $\begin{array}{l}\text { 'This is the servant of } \\
\text { the Lord, the all merci- } \\
\text { ful' }\end{array}$ \\
\hline \multicolumn{4}{|l|}{$\begin{array}{l}\text { Lower line } \\
\text { (Soninke) }\end{array}$} \\
\hline كِنِ نِمَدَنَ & nimadana kumini & neemandaana kome ni & $\begin{array}{l}\text { 'This is the servant of } \\
\text { the comforter' }\end{array}$ \\
\hline
\end{tabular}




\begin{tabular}{llll}
\hline Text & Transliteration & Transcription & Interpretation \\
\hline
\end{tabular}

Second pair of glosses for al-m 'aruf (literally 'known')

Upper line

(Mandinka)

أَمُلْبِ تِ تِ

a mulufi ti

a mu lónfén ti

'This is the thing that

is known'

Lower line

(Soninke)

تثنِنِ

tuyitini

tuyinte ni

'This is the knowledgeable person'

If this interpretation is correct, then this manuscript was probably produced or used somewhere in Senegal, the Gambia or Guinea-Bissau.

\section{Concluding remarks and further questions}

As has been shown above, a number of paratextual elements in OM manuscripts provide various items of temporal and spatial information about their production and sometimes even their transmission. Several places (Suwarekunda, Bani Isra'il) and personal names (Darame, Faati, Jakite, Jawara, Kassama, etc.) recorded in the colophons suggest that these manuscripts may be traced back to the Jakhanke scholarly communities in eastern Senegal, the Gambia and northern Guinea. Other non-explicit information from paratextual components such as the linguistic features of the glosses or language of the colophon can also contribute to the identification of the places pertaining to these manuscripts, since different vernacular languages were spoken in different regions. ${ }^{48}$ With such information extracted from

\footnotetext{
48 The linguistic peculiarities of the Soninke language used in the glosses in several manuscripts, punctuated by deformation of certain words due to the influence of Mandinka, as well as the additional layer of Mandinka glosses marked as fi kalāminā, 'in our words', suggests that Soninke was not the first language of its users. According to some sources (see e.g. Sanneh 1979, Sanneh 1989:16; Sylla 2012), Soninke has been used as an exegetical language among the Jakhanke. Tal Tamari pointed out - on many occasions in personal communication and during the OMRN sessions in 2012, 2013 and 2015 as well as in Tamari (in press) - that during her fieldwork in 2004 in many areas of the Gambia, "Soninke was used as a language of Islamic education, even by Mandinka-speaking scholars with their Mandinka-speaking students - as well as, of course, by Soninke-speaking scholars with both their Soninke- and Mandinka-speaking students”. This would explain why Mandinka
} 
paratexts, it is possible to identify the place where the manuscript or codicological unit was originally produced.

However, caution is necessary regarding any further analysis of paratexts in OM manuscripts. First, in many of the above-mentioned examples, even if we are able to read place names in colophons, it is often impossible to accurately attribute the manuscript to a particular location because several places bear identical names in the same country or in different countries in West Africa. In the rare cases where some additional information about the place names is provided, such as in manuscript OR/Arab 11 (2) kept at Palace Green Library, Durham, it is much easier to find the exact location of this place. The place name marked in the colophon consists of two elements: [ $\mathrm{ku}^{\mathrm{n}} \mathrm{bu} \mathrm{yu}^{\mathrm{n}} \mathrm{dumu}$ ] Kombo Yumdumu, 'Yundumu of Kombo'. Most likely, a reference is being made here to the locality named Yundum (as it is marked on the modern map and mentioned in some literature) ${ }^{49}$ or Yumdumu located in Kombo, a kingdom once situated on the territory of the modern state of the Gambia. ${ }^{50}$ This assumption is also supported by the information from the acquisition note, which records that the manuscript was acquired in 1853 in the town of Sabaji (Sabagee), the Gambia. The second instance where the name of a smaller locality is accompanied by the name of the country is attested in the manuscript kept by BULAC, Ms.Ara.219bis DI.1326. According to the information from the colophon, the owner, Umaru Sylla, lived in [kusarā dhābi kuda] Kusara Jaabikunda, 'Jaabikunda of Kusara', where Jaabikunda is the name of a big Jakhanke village in the country of Kusara, located in what is now Guinea-Bissau. ${ }^{51}$ However, in other cases, when no further information about the country is available, exact identification of the place's geographical location will be relatively hard.

In addition, toponyms in the colophons may be ambiguous in many cases, since they are not vocalised and can therefore be read in several different ways. For example, the place name in the colophon of the manuscript JRL 780 [825], fols. 1a-12, is written as [kt knd]. The language used in the glosses suggests that the manuscript could originate from Senegal, the Gambia or Guinea-Bissau, yet there are still at least four possible locations that the name might refer to:

appears in colophons and sometimes in the glosses of certain manuscripts (accompanying the glosses in Soninke). During my fieldwork in southern Senegal in 2014-2015, I also found that Soninke had been actively used as the intermediary language of Islamic learning until quite recently, before being replaced by instruction in Mandinka.

49 Quinn 1972.

50 Innes 1974.

51 Giesing / Vydrine 2007. 
Kutakunda (Kootacunda) in Wuli, the Gambia, Kantakunda in Guinea-Bissau, Kinteh Kunda, and Konte Kunda in Badibu, the Gambia.

Furthermore, although various pieces of spatial information about a manuscript can often be found in its colophons, temporal information is scanty. In many manuscripts, even if some indications of time are provided, they mostly just refer to a day of the week, while the exact date of the manuscript's production remains largely unknown.

Finally, the difficulty modern scholars encounter in locating OM manuscripts in time and space is aggravated by the fact that not all the original manuscripts are accessible. Some are available for examination, but they can only be seen in black-and-white digitised microfilms. In such cases, the poor quality of the images can significantly complicate their analysis. In other cases, it may even be impossible to glean any relevant information from colophons because of severe damage to the paper, spots or illegible handwriting. ${ }^{52}$

As a first attempt to examine paratexts in the OM manuscripts, this study focuses primarily on temporal and spatial information in various paratextual components, in particular colophons and glosses. It is expected that other sources such as oral commentaries, reports made by colonial officials and anthropological and ethnographical accounts by European travellers, and the large number of manuscripts and works composed by West African scholars, may help overcome some of the difficulties and thus solve some of the remaining ambiguities.

\section{Manuscripts}

JRL 780 [825], fols. 1a-12b, a copy of a poem composed by Ibn Sulaym al-Awjilī (d. 1801/2). BnF Ms Arabe 5586, fols. 1a-177a, a copy of al-Risāla composed by Ibn Abī Zayd al-Qayrawani (d. 996).

BULAC Ms.Ara.219bis DP 8-18, a copy of Jawāhir min al-kalām composed by Ibn Sulaym alAwjilī (d. 1801/2).

TCD MS 2689, fols. 1a-6a, an anonymous work on cosmogony.

Ms Arabe 5657, fols. 1a-28b, a copy of Dalīl al-qā'id li-kashf asār șifāt al-wāhịid composed by Ibn Sulaym al-Awjilī (d. 1801/2).

Ms Arabe 5657, fols. 36a-84b, a copy of Iḍ̄a'at al-dujunna fí 'aqā'ahl al-sunna composed by Aḥmad b. Muḥammad al-Maqqārī (d. 1632).

52 An ongoing collaboration with project Z01, 'Manuscript Analysis to Recover Lost Writing', which is being run at SFB 950, 'Manuscript Cultures in Asia, Africa and Europe' / CSMC, Hamburg, is attempting to recover such illegible words. 
Ms Arabe 5657, fols. 109b-125a, a copy of Tajrīd fi kalimat al-tawhīd, composed by Aḥmad b. Muḥammad al-Ghazālī.

BMT Ms 2234, pp. 833-843, a copy of Dalīl al-qā’id li-kashf asār șifät al-wāhid composed by Ibn Sulaym al-Awjilī (d. 1801/2).

BULAC Ms.Ara.112b, a copy of Tafsīr al-Jalālayn composed by Jalāl al-Dīn Muḥammad alMaḥalīi (d. 1459) and Jalālal-Dīn 'Abd al-Raḥmān al-Suyūṭī (d. 1505).

TCD MS 2179, a copy of al-Risāla composed by Ibn Abī Zayd al-Qayrawani (d. 996).

TCD MS 3499, fols. 160b-296a, a copy of al-'Aqĩda al-kubrā composed by Muhammad bin Yusuf al-Sanūsī (d. 1486).

TCD MS 3499, fols. 11b-42b, a copy of Abāb al-'ulamā' composed by Ibn al-Nasāj.

TCD MS 3499, fols. 43b-130b, a copy of Tajrīd fi kalimat al-tawhīd composed by Aḥmad b. Muḥammad al-Ghazālī (d. 1123).

MAAO AF14722, fols. 5ab and 102a-174a (in disorder), unidentified.

PGL Or/Arab 11 (2), fols. 1-27, a copy of al-'Aqīda al-kubrā composed by Muhammad bin Yusuf al-Sanūsī (d. 1486).

BULAC Ms.Ara.165a DI.246-250, unidentified.

BULAC Ms.Ara.219bis DP 72-74, unidentified.

BULAC Ms.Ara.219bis DP 1324-1326, unidentified.

\section{References}

(Note: the name 'Vydrin' is sometimes spelt 'Vydrine' in different sources. Here I have quoted this author according to the spelling that is found in each publication.)

Bello, Muhammad (1951). Infāq al-maysūr fĩ ta'rīkh bilād al-Takrūr. Edited by C.E.J. Whitting. London: Luzac.

Bondarev, Dmitry (2013). “Qur’anic Exegesis in Old Kanembu: Linguistic Precision for Better Interpretation”. In: Journal of Qur'anic Studies 15/3, 56-83.

Bondarev, Dmitry (2014). "Multiglossia in West African Manuscripts: A Case of Borno, Nigeria". In: Quenzer, Jörg B. / Bondarev, Dmitry / Sobisch, Jan-Ulrich (eds.): Manuscript Cultures: Mapping the Field. Berlin: de Gruyter, 113-155.

Bondarev, Dmitry / Tijani, Abba (2014). "Performance of Multilayered Literacy: Tarjumo of the Kanuri Muslim Scholar”. In: Juffermans, Kasper / Asfaha, Yonas M. / Abdelhay, Ashraf K. (eds.): African Literacies: Ideologies, Scripts, Education. Newcastle upon Tyne: Cambridge Scholars Publishing, 118-146.

Brenner, Louis / Ghali, Noureddine / Mahibou, Sidi Mohamed (1985). Inventaire de la bibliothèque 'Umarienne de Ségou, conservée à la bibliothèque nationale, Paris. Paris: Éditions du Centre national de la recherche scientifique.

Creissels, Denis (2011). Lexique mandinka-français. <http://www.deniscreissels.fr/public/ Creissels-lexique_mandinka_2011.pdf> (viewed on 27.11.2015).

Creissels, Denis / Jatta, Sidia / Jobarteh, Kalifa (1982). „Lexique mandinka-français“. In: Mandenkan 3, 1-207.

Davydov, Artem (2012). “On Souleymane Kanté's Translation of the Quran into the Maninka Language”. In: Mandenkan 48, 3-20. 
Delafosse, Maurice (1913). Traditions historiques et légendaires du Soudan occidental. Paris: Publications du Comité de l'Afrique française.

Diagana, Ousmane Moussa (2011). Dictionnaire soninké-français (Mauritanie). Paris: Karthala.

Dobronravin, Nikolay (2012). "Arabic and Ajami Colophons in West Africa and 19th Century Brazil”. In: St. Petersburg Annual of Asian and African Studies 1, 90-94.

Dobronravin, Nikolay (2013). “Classical Hausa' Glosses in a Nineteenth-century Qur'anic Manuscript: A Case of “Translational Reading” in Sudanic Africa?". In: Journal of Qur'anic Studies 15/3, 84-122.

Dobronravin, Nikolay / Gittins, Estelle (2013). African and African Diaspora Manuscripts in Trinity College Library. <https://manuscriptsattrinity.wordpress.com/2013/01/> (viewed on 27.11.2015).

Donaldson, Coleman (2013). "Jula Ajami in Burkina Faso: A Grassroots Literacy in the Former Kong Empire". In: Working Papers in Educational Linguistics, 28/2, 19-36.

Dumestre, Gérard / Vydrin, Valentin (2014). "Manding Ajami Samples: Mandinka and Bamana". In: Mumin, Meikal / Versteegh, Kees (eds.): The Arabic Script in Africa: Studies in the Use of a Writing System, Leiden/ Boston: Brill, 225-260.

Gamble, David P. (1996). The South Bank of the Gambia: Places, People, and Population (a) Kantora and Fuladuu. Gambian Studies 30. Brisbane (CA).

Gamble, David P. (1999). The North Bank of the Gambia: Places, People and Population (c) the Nyooni, Jookadu, and Badibu Districts. Gambian Studies 38, Brisbane (CA).

Gamble, David P. (2000). Postmortem: A Study of the Gambian Section of Alex Haley's 'Roots'. Gambian Studies 39. Brisbane (CA).

Gamble, David P. (2006). The South Bank of the Gambia: Places, People, and Population (d) the Kombo Districts. Gambian Studies 51, Brisbane (CA).

Gessain, Robert (1963). “Introduction à l'étude du Sénégal oriental (Cercle de Kédougou)”. In: Cahiers du centre de recherches anthropologiques 11/5, 1-2 and 5-85.

Giesing, Cornelia / Vydrine, Valentin (2007). Ta:rikh Mandinka de Bijini (Guinée-Bissau): La Mémoire des Mandinka et Sòoninkee du Kaabu. Leiden / Boston: Brill.

Hamès, Constant (1987). “Taktub ou la magie de l'écriture islamique. Textes soninkés à l'usage magique”. In: Arabica, T.34, Fasc. 3, 305-325.

Hunwick, John O. (ed.) (1995). Arabic Literature of Africa: the Writings of Centreak Sudanic Africa. Vol 2. Leiden: Brill.

Innes, Gordon (1974). Sunjata: Three Mandinka Versions. London: SOAS.

Innes, Gordon (1976). Kaabu and Fuladu: Historical Narratives of the Gambian Mandinka. London: SOAS.

Marty, Paul (1917). Études sur l'islam au Sénégal: Les Personnes. Paris: E. Leroux.

Marty, Paul (1921). Islam en Guinée: Fouta Diallon. Paris: E. Leroux.

Ngom, Fallou (2010). “Ajami Scripts in The Senegalese Speech Community”. In: Journal of Arabic and Islamic Studies 10, 1-23.

Quinn, Charlotte A. (1972). Mandingo Kingdoms of the Senegambia; Traditionalism, Islam, and European Expansion. London: Longman.

Ross, Eric (2011). "A Historical Geography of the Trans-Saharan Trade”. In: Krätli, Graziano / Lydon, Ghislaine (eds.): The Trans-Saharan Book Trade. Leiden / Boston: Brill, 1-34.

Sanneh, Lamin O. (1979). The Jakhanke: The History of an Islamic Clerical People of the Senegambia. London: International African Institute.

Sanneh, Lamin 0. (1989). The Jakhanke Muslim Clerics: A religious and Historical Study of Islam in Senegambia. Lanham / New York / London: University Press of America. 
Schaffer, Matthew (1975). "Pakao Book: an Introduction to Pakao Expansion and Social Structure by Virtue of an Indigenous Manuscript". In: African Languages/Langues Africaines 1, 96-123.

Schaffer, Matthew (2003). Djinns, Stars and Warriors: Mandinka Legends from Pakao, Senegal. Leiden / Boston: Brill.

Smeltzer, Brad / Smeltzer, Susan (1997). Xannun xaranka Sooninken do Tubaabun xannen sefetaanu. Lexique soninké-français, index français-soninké. Bamako: SIL-Mali.

Smith, Pierre (1965). “Les Diakhanké. Histoire d’une dispersion”. In: Bulletins et mémoires de la société d'anthropologie de Paris, 8 - XI, 231-262.

Sow, Alfa Ibrahim (1968). Chroniques et récits du Fouta Djalon. Paris: Klincksieck.

Sylla, Abdoul Kader Taslimanka (2012). Baní Israël du Sénégal ou ahl Diakha peuple de diaspora. Paris: Publibook.

Tamari, Tal (1994). "Cinq textes bambara en caractères arabes: Présentation, traduction, analyse du système graphique”. In: Islam et sociétés au sud du Sahara 8, 97-121.

Tamari, Tal (1996). “L’Exégèse coranique (tafsîr) en milieu Mandingue. Rapport préliminaire sur une recherche en cours". In: Islam et sociétés au sud du Sahara 10, 45-79.

Tamari, Tal (2002). “Islamic Higher Education in West Africa: Some Examples from Mali”. In: Bierschenk, Thomas / Stauth, Georg (eds.): Yearbook of the Sociology of Islam 4. Münster: LIT Verlag, 91-128.

Tamari, Tal (2005). "La prose littéraire arabe en traduction bambara: une maqama d'al-Hariri”. In: Baumgardt, Ursula / Derive, Jean (eds.): Paroles nomades. Écrits d'ethnolinguistique en hommage à Christiane Seydou. Paris: Karthala, 431-463.

Tamari, Tal (2006). “'’'Enseignement islamique traditionnel de niveau avancé: Cursus, pédagogie, implications culturelles et perspectives comparatives”. In: Mande Studies 8, 39-62.

Tamari, Tal (2009). "The Role of National Languages in Mali’s Modernising Islamic Schools (Madrasa)”. In: Brock-Utne, Birgit / Skattum, Ingse (eds.): Languages and Education in Africa: A Comparative and Transdisciplinary Analysis. Bristol Papers in Education 4, Bristol: Symposium Books, 163-174.

Tamari, Tal (2013a). “A Bamana Commentary on Sūrat al-Wāq'ia: A Linguistic and Stylistic Analysis”. In: Journal of Qur'anic Studies 15/ 3, 123-183.

Tamari, Tal (2013b). “Un poème arabe en traduction bambara: la Mu'allaqa d'Imru' I-Qays”. In: Hirsch, Bertrand / Fauvelle-Aymar, François-Xavier (eds.): Les ruses de l'historien. Essais d'Afrique et d'ailleurs en hommage à Jean Boulègue. Paris: Karthala, 441-487.

Tamari, Tal (in press). "Styles of Islamic Education. Perspectives from Mali, Guinea and The Gambia”. In: Launay, Robert G. (ed.): Writing Boards and Blackboards: Islamic Education in Africa. Bloomington: Indiana University Press.

Tamari, Tal / Bondarev, Dmitry (2013). “Introduction and Annotated Bibliography”. In: Journal of Qur'anic Studies 15/3, 1-55.

Vydrine, Valentin (1998). "Sur l'écriture Mandingue et Mandé en caractères arabes (Mandinka, Bambara, Soussou, Mogofin)". In: Mandenkan 33, 1-87.

Vydrin, Valentin (2014). “Ajami Scripts for Mande Languages”. In: Mumin, Meikal / Versteegh, Kees (eds.): The Arabic Script in Africa: Studies in the Use of a Writing System. Leiden/ Boston: Brill, 199-224.

Wilks, Ivor (2000). "The Juula and the Expansion of Islam into the Forest”. In: Levtzion, Nehemia / Pouwels, Randall L. (eds.): History of Islam in Africa. Athens (OH): Ohio University Press, 93-115. 
